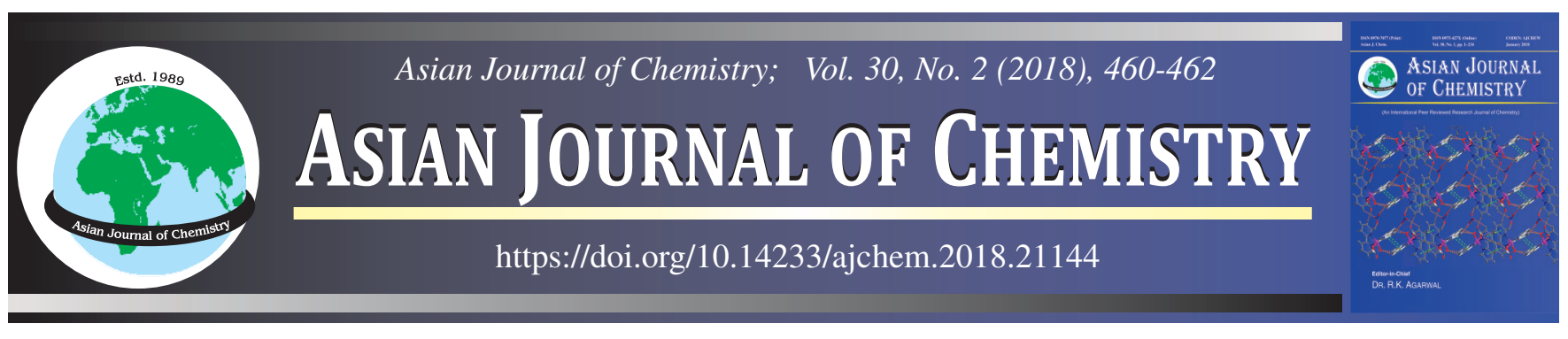

\title{
Synthesis and Characterization of Niobium and Tantalum Complexes with Bidentate Ligand and its use in Ring Opening Polymerization of $\varepsilon$-Caprolactone
}

Yahya F. Al-Khafaji ${ }^{1, *}$, Mohammed R. Al-Lami ${ }^{2}$, Ahmed S. Abbas ${ }^{1}$, Ameer Al-Ameri ${ }^{1}$ and Ahmed Falah Albo Mousa ${ }^{1}$

${ }^{1}$ Department of Chemistry, Faculty of Science, University of Babylon, Babylon, Iraq

${ }^{2}$ The Ministry of Higher Education and Scientific Research, Research Development Department, Baghdad, Iraq

*Corresponding author: Tel: +964 7805141952; E-mail: yfalkhafaji@gmail.com

Received: 21 October 2017;

Accepted: 30 November 2017;

Published online: 31 December 2017;

AJC-18722

Reaction of two equivalents of the bidentate $2,2^{\prime}-\mathrm{PhCH}\left[4,6-(t-\mathrm{Bu})_{2} \mathrm{C}_{6} \mathrm{H}_{2} \mathrm{OH}\right]_{2}$ with one equivalent of niobium pentachloride gave the
complex $\mathrm{Nb}\left\{2,2^{\prime}-\mathrm{PhCH}\left[4,6-(t-\mathrm{Bu})_{2} \mathrm{C}_{6} \mathrm{H}_{2} \mathrm{O}\right]_{2}\right\}_{2}(\mathbf{1})$. Similar use of two equivalents of the same ligand with one equivalents tantalum
pentachloride afforded Ta $\left\{2,2^{\prime}-\mathrm{PhCH}\left[4,6-(t-\mathrm{Bu})_{2} \mathrm{C}_{6} \mathrm{H}_{2} \mathrm{O}\right]_{2}\right\}_{2}(2)$. The molecular structure of complexes $\mathbf{1}$ and $\mathbf{2}$ have been characterized by
IR and ${ }^{1} \mathrm{H}$ NMR. Both complexes were investigated as catalysts for polymerization of cyclic esters ( 8 -caprolactone) with no solvent at
various time at $110{ }^{\circ} \mathrm{C}$. In all cases the polymer produced was of high yield percent.

Keywords: Niobium(V), Tantalum(V), Phenolate, $\varepsilon$-Caprolactone, Ring opening polymerization.

ᄂ - - - - - - - - - - - - - - - - - - - - - - - - - - - - -

\section{INTRODUCTION}

Biodegradable polymeric material produced via ring opening polymerization (ROP) of $\varepsilon$-caprolactone continues to catch much attention by reason of a wide range of applications $[1,2]$. A variety of catalysts have been used as initiators for ring opening polymerization and coordination chemistry shows a significant role in this process, the use of niobium and tantalum compounds received more attention due to no toxicity related with these metals. According to the literature a few papers published on these metals complexes as catalysts toward polymerization of lactide, lactone or ethylene [3-6]. The use of Schiff base ligation has received more interest because of easy to prepare [7] and versatile applications of Schiff base and their complexes as biological activity, antifungal properties, anticancer properties, application in modern technologies, application in synthesis and chemical analysis [8-13].

In this paper, two complexes of niobium and tantalum were synthesized, characterized and their catalytic behaviour was investigated. As compared with one equivalent of 2,2'$\mathrm{PhCH}\left[4,6-(t-\mathrm{Bu})_{2} \mathrm{C}_{6} \mathrm{H}_{2} \mathrm{OH}\right]_{2}$ prepared by Redshaw et al. [14] and Müller et al. [15], we have found that by employing two equivalent of 2,2'- $\mathrm{PhCH}\left[4,6-(t-\mathrm{Bu})_{2} \mathrm{C}_{6} \mathrm{H}_{2} \mathrm{OH}\right]_{2}$ ligand can be beneficial in term of control of polymerization.

\section{EXPERIMENTAL}

Dried environment was carried out throughout the experiment. Solvents were dried before use. Infrared spctra were recorded using Nicolet Avatar 360 FTIR spectrometer. ${ }^{1} \mathrm{H}$ NMR were recorded at $400 \mathrm{MHz}$ in a (VXR $400 \mathrm{~S}$ ) spectrometer.

Synthesis of $\mathrm{Nb}\left\{2,2^{\prime}-\mathrm{PhCH}\left[4,6-(t-\mathrm{Bu})_{2} \mathrm{C}_{6} \mathrm{H}_{2} \mathrm{O}\right]_{2}\right\}_{2}$ complex (1): A toluene solution of $20 \mathrm{~mL}$ of $2,2^{\prime}-\mathrm{PhCH}\left[4,6-(t-\mathrm{Bu})_{2}\right.$ $\left.\mathrm{C}_{6} \mathrm{H}_{2} \mathrm{OH}\right]_{2}(1 \mathrm{~g}, 1.99 \mathrm{mmol})$ and $\mathrm{NbCl}_{5}(1.12 \mathrm{~g}, 0.99 \mathrm{mmol})$ was dissolved in $10 \mathrm{~mL}$ toluene and mixed with ligand solution. The mixture was refluxed for $6 \mathrm{~h}$ followed by the removal of volatiles and extracted the solid into acetonitrile $(20 \mathrm{~mL})$ to give red coloured solid complex $\mathbf{1}$.

Synthesis of Ta $\left\{2,2^{\prime}-\mathrm{PhCH}\left[4,6-(t-\mathrm{Bu})_{2} \mathrm{C}_{6} \mathrm{H}_{2} \mathrm{O}\right]_{2}\right\}_{2}$ complex (2): By following same procedure as described for synthesis of complex 1, the complex 2 was synthesized by the reaction of $\mathrm{TaCl}_{5}(1.21 \mathrm{~g}, 0.99 \mathrm{mmol})$ with $20 \mathrm{~mL}$ of 2,2'-PhCH[4,6- $(t-$ $\left.\mathrm{Bu})_{2} \mathrm{C}_{6} \mathrm{H}_{2} \mathrm{OH}\right]_{2}(1.00 \mathrm{~g}, 1.99 \mathrm{mmol})$ to give pink coloured solid complex 2.

Ring opening polymerization: Complex 1 or $2(0.30 \mathrm{~g}$, $266.46 \mu \mathrm{mol}), \varepsilon$-caprolactone $(6.08 \mathrm{~mL}, 52.39 \mathrm{mmol})$ and alcohol $(0.01 \mathrm{~mL}, 118.3 \mu \mathrm{mol})$ mixed together in absence of solvent and the system was placed in an oil bath at $100{ }^{\circ} \mathrm{C}$. After $1 \mathrm{~h}$, the mixture quenched by added methanol $(250 \mathrm{~mL})$.

\section{RESULTS AND DISCUSSION}

The compound 2,2'-PhCH[4,6- $\left.(t-\mathrm{Bu})_{2} \mathrm{C}_{6} \mathrm{H}_{2} \mathrm{OH}\right]_{2}$ was prepared according to reported procedure $[4,14]$. Reaction of ligand with toluene solution of niobium pentachloride $(2: 1)$ ratio and tantalum pentachloride $(2: 1)$ ratio has resulted in the formation of $\mathrm{Nb}\left\{2,2^{\prime}-\mathrm{PhCH}\left[4,6-(t-\mathrm{Bu})_{2} \mathrm{C}_{6} \mathrm{H}_{2} \mathrm{O}\right]_{2}\right\}_{2}$ (1) complex and $\mathrm{Ta}\left\{2,2^{\prime}-\mathrm{PhCH}\left[4,6-(t-\mathrm{Bu})_{2} \mathrm{C}_{6} \mathrm{H}_{2} \mathrm{O}\right]_{2}\right\}_{2}$ (2) complexes. 
<smiles>CC(C)(C)c1cc(C(c2ccccc2)c2cc(C(C)(C)C)c3cc2OC3C(C)(C)C)c(Oc2c(C(c3ccccc3)c3cc(C(C)(C)C)cc(C(C)(C)C)c3Oc3c(C(C)(C)C)cc(C(C)(C)C)cc3C(C)(C)C)cc(C(C)(C)C)cc2C(C)(C)C)c(C(C)(C)C)c1</smiles>

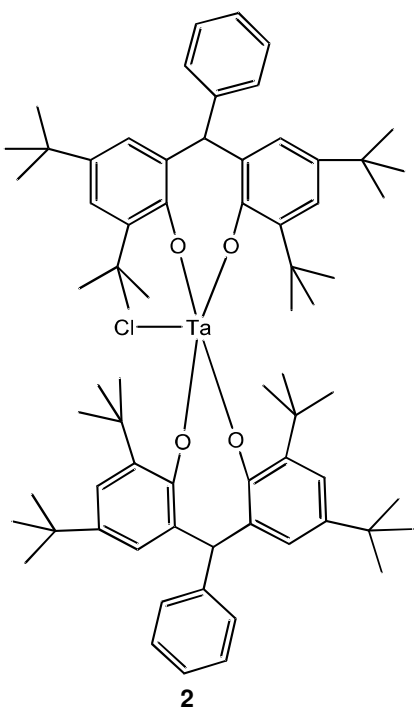

Structure of $\mathrm{Nb}\left\{2,2^{\prime}-\mathrm{PhCH}\left[4,6-(t-\mathrm{Bu})_{2} \mathrm{C}_{6} \mathrm{H}_{2} \mathrm{O}\right]_{2}\right\}_{2}(\mathbf{1})$ and $\mathrm{Ta}\left\{2,2^{\prime}-\mathrm{PhCH}\left[4,6-(t-\mathrm{Bu})_{2} \mathrm{C}_{6} \mathrm{H}_{2} \mathrm{O}\right]_{2}\right\}_{2}(\mathbf{2})$

Infrared spectra: The IR spectra of both complexes presented a characteristic absorption single at $2900 \mathrm{~cm}^{-1}$ belonging to $t$-butyl group while peaks at $3200-3100 \mathrm{~cm}^{-1}$ shifted to shorter wave length indicated that coordination has happened through -OH group.

${ }^{1}$ H NMR spectra: The ${ }^{1} \mathrm{H}$ NMR spectra of complexes was performed in $\mathrm{CDCl}_{3}$ at room temperature. The spectrum of complex 1 revealed the signals at $1.27(\mathrm{~s}, 36 \mathrm{H}, t-\mathrm{Bu}), 1.30$ $(\mathrm{s}, 36 \mathrm{H}, t-\mathrm{Bu}), 3.77$ (s, $1 \mathrm{H}, \mathrm{CH}$-bridge) and 6.67-7.51 (m, 18H, Ar-H) (Fig. 1). For complex 2, ${ }^{1} \mathrm{H}$ NMR spectrum showed the signals at $1.29(\mathrm{~s}, 18 \mathrm{H}, t-\mathrm{Bu}), 1.42(\mathrm{~s}, 18 \mathrm{H}, t-\mathrm{Bu}), 4.43(\mathrm{~s}, 1 \mathrm{H}$, $\mathrm{CH}$ bridge) and 7.15-7.43 (m, 18H, Ar-H) (Fig. 2).

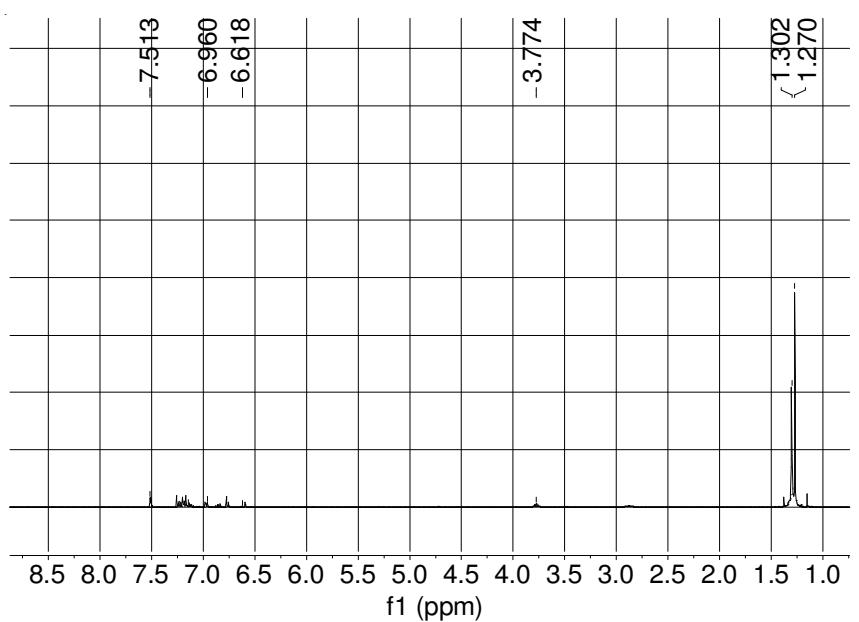

Fig. 1. ${ }^{1} \mathrm{H}$ NMR spectrum of complex 1

Ring opening polymerization of $\varepsilon$-caprolactone: The ability of synthesized complexes toward the ring opening polymerization of $\varepsilon$-caprolactone were assessed (Scheme-I). Polymerization of $\varepsilon$-caprolactone by complexes $\mathbf{1}$ and $\mathbf{2}$ which includes the phenoxide group were noted to be active (Table-1). The polymer molecular weight $\left(\mathrm{M}_{\mathrm{n}}\right)$ obtained by Ta catalyst is much lower as compared to $\mathrm{Nb}$ catalyst [16].

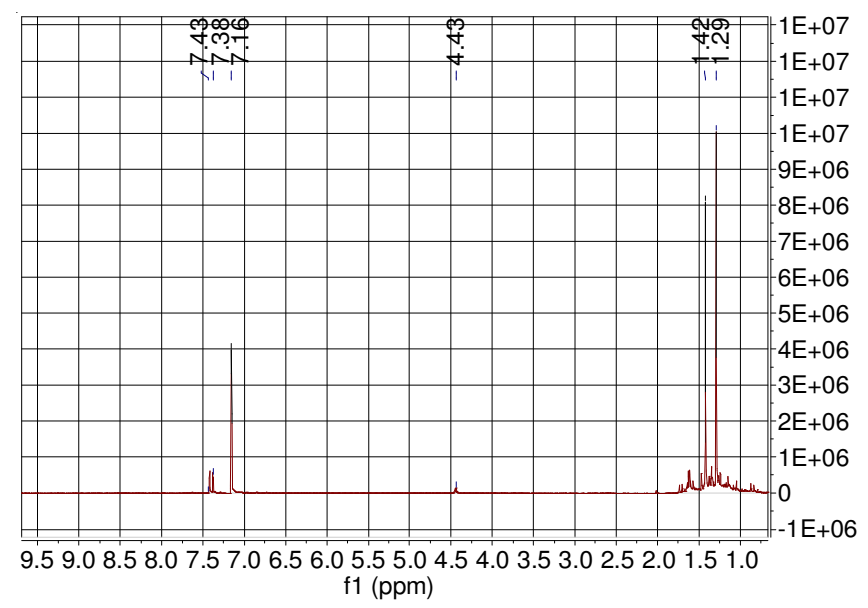

Fig. 2. ${ }^{1} \mathrm{H}$ NMR spectrum of complex 2

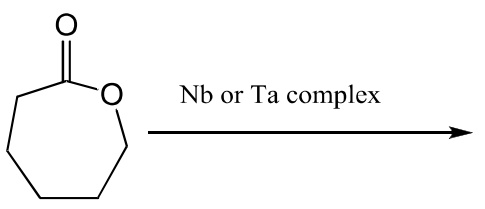<smiles>CC(CCCCCCOC(=O)CCCCCO)C(=O)OCc1ccccc1</smiles>

Scheme-I: Ring opening polymerization of $\varepsilon$-CL

TABLE-1

POLYMERIZATION OF $\varepsilon$-CAPROLACTONE USING COMPOUNDS 1 AND $2^{\mathrm{a}}$

\begin{tabular}{ccccc}
\hline Catalyst & Yield $(\%)$ & Time $(\min )$ & $\mathrm{M}_{\mathrm{n}}^{\mathrm{b}}$ & PDI $^{\mathrm{c}}$ \\
\hline Nb complex & 81 & 30 & 12900 & 1.10 \\
Ta complex & 77 & 40 & 6500 & 1.29 \\
\hline
\end{tabular}

${ }^{\mathrm{a} C}$ Conditions: $0.0123 \mathrm{~mol}$ of complexes; $1.0 \mathrm{M} \varepsilon$-CL in toluene. $\mathrm{CL}$ : [cat] : $\mathrm{BnOH}=200: 1: 1{ }^{\mathrm{b}, \mathrm{c}}$ from GPC.

\section{ACKNOWLEDGEMENTS}

The authors thanks Ministry of Higher Education and Scientific Research, Research and Development Department and Department of Chemistry, Faculty of Science, University of Babylon, Babylon, Iraq for supporting this work.

\section{REFERENCES}

1. A.L. Sisson, D. Ekinci and A. Lendlein, Polymer, 54, 4333 (2013); https://doi.org/10.1016/j.polymer.2013.04.045.

2. M.A. Woodruff and D.W. Hutmacher, Prog. Polym. Sci., 35, 1217 (2010); https://doi.org/10.1016/j.progpolymsci.2010.04.002.

3. Y. Al-Khafaji, X. Sun, T.J. Prior, M.R. Elsegood and C. Redshaw, Dalton Trans., 44, 12349 (2015);

https://doi.org/10.1039/C5DT00272A

4. T.K. Saha, M. Mandal, M. Thunga, D. Chakraborty and V. Ramkumar, Dalton Trans., 42, 10304 (2013); https://doi.org/10.1039/c3dt50752a.

5. C. Chi-T, L.H. Doerrer, V.C. Williams and M.L.H. Green, J. Chem. Soc., Dalton Trans., 967 (2000).

6. J.M. Decams, S. Daniele, L.G. Hubert-Pfalzgraf, J. Vaissermann and S. Lecocq, Polyhedron, 20, 2405 (2001); https://doi.org/10.1016/S0277-5387(01)00834-8. 
7. W. Qin, S. Long, M. Panunzio and S. Biondi, Molecules, 18, 12264 (2013); https://doi.org/10.3390/molecules 181012264 .

8. S. Sundriyal, R.K. Sharma and R. Jain, Curr. Med. Chem., 13, 1321 (2006); https://doi.org/10.2174/092986706776873023.

9. M. Jesmin, M.M. Ali and J.A. Khanam, Thail. J. Pharm. Sci., 34, 20 (2010).

10. K. Tanaka, R. Shimoura and M.R. Caira, Tetrahedron Lett., 51, 449 (2010);

https://doi.org/10.1016/j.tetlet.2009.11.062.

11. P. Mastalerz, Organic Chemistry Edition, Wroclaw, Poland (1996).

12. X. Wang, K.-Q. Zhao, Y. Al-Khafaji, S. Mo, T.J. Prior, M.R.J. Elsegood and C. Redshaw, Eur. J. Inorg. Chem., 1951 (2017); https://doi.org/10.1002/ejic.201601415.
13. R. Hassan, H. Arida, M. Montasser and N.A. Latif, J. Chem., Article ID 240568 (2013); https://doi.org/10.1155/2013/240568.

14. Y. Al-Khafaji, T.J. Prior, M.R.J. Elsegood and C. Redshaw, Catalysts, 5, 1928 (2015); https://doi.org/10.3390/catal5041928.

15. E. Müller, A. Schick and R. Mayer, Eur. J. Inorg. Chem., 93, 2649 (1960);

https://doi.org/10.1002/cber.19600931133.

16. T. Saha, M. Mandal, M. Thunga, D. Chakraborty and V. Ramkuma, Dalton Trans., 42, 10304 (2013); https://doi.org/10.1039/C3DT50752A 